\title{
Seizure increases electroencephalographic abnormalities in children with tuberculous meningitis
}

\author{
Prastiya Indra Gunawan* and Darto Saharso*
}

\section{ABSTRACT}

\section{BACKGROUND}

Tuberculous meningitis (TBM) is a severe intracranial infection with fatal outcomes, permanent disabilities, and electroencephalographic (EEG) abnormalities. Seizures may occur in TBM. The EEG findings in TBM vary according to the site of the inflammatory process. There are few studies describing the EEG patterns and clinical manifestations of TBM. The objective of this study was to investigate the correlation between clinical findings and EEG patterns in children with TBM.

\section{METHODS}

A study of cross-sectional design using medical records was conducted on 12 children with TBM, with their EEG patterns classified as abnormal and normal. Clinical manifestations such as seizures, altered consciousness, headache or fever were collected. A positive cerebrospinal fluids Mycobacterium tuberculosis culture was considered to indicate definitive TBM. Abnormal EEG descriptions were classified into abnormal I, II or III. Correlation between EEG pattern and clinical manifestation were analyzed with Fisher's exact test.

\section{RESULTS}

The study found cases of 12 children with TBM, the majority presenting with seizures, decreased consciousness and fever. Abnormal EEGs were found in $75 \%$ of children and $77 \%$ of them showed epileptogenic activities. The EEG results mostly described epileptogenic potentials in the frontotemporal region. There was a significant correlation between EEG abnormality and seizures in children with TBM $(\mathrm{p}<0.05)$.

\section{CONCLUSIONS}

The EEG pattern in children with TBM varies, and EEG abnormalities were more frequently localized in the frontotemporal region. Seizures were associated with EEG abnormalities in children with TBM. EEG abnormalities occurring simultaneously with seizures may predict the occurrence of seizures.

Keywords: Tuberculous meningitis, EEG, children
Department of Pediatrics,

Faculty of Medicine,

Airlangga University, Surabaya

\section{Correspondence:}

dr. Prastiya Indra Gunawan, SpA

Department of Pediatrics,

Faculty of Medicine,

Airlangga University

RSU Dr. Soetomo

Jl. Mayjen. Prof. Dr. Moestopo 4-6,

Surabaya 60132

Email: prastiya_ig@yahoo.co.id

Mobile: +628113429476

Fax: +6231 5501748

Univ Med 2015;34:161-7

DOI: 10.18051/UnivMed.2016.v35.161-167 pISSN: 1907-3062 / eISSN: 2407-2230

This open access article is distributed under a Creative Commons Attribution-Non Commercial-Share Alike 4.0 International

License 


\section{Kejang meningkatkan kelainan elektro ensefalogram pada anak dengan meningitis tuberkulosis}

\section{ABSTRAK}

\section{LATAR BELAKANG}

Meningitis tuberkulosis (MT) adalah infeksi intrakranial berat yang dapat berakibat fatal, kecacatan permanen dan menunjukkan keabnormalan pada hasil elektro ensefalogram (EEG). Kejang dapat terjadi selama proses MT. Hasil EEG pada MT bervariasi tergantung pada daerah setempat dimana proses inflamasi berlangsung. Studi yang mendiskripsikan tentang pola EEG dan manifestasi klinis pada MT cukup terbatas. Tujuan dari penelitian ini adalah untuk menentukan adanya hubungan antara manifestasi klinis dengan pola EEG pada anak dengan MT.

\section{METODE}

Studi potong lintang menggunakan catatan medik dilakukan pada anak dengan MT. Sebanyak 12 anak dengan MT dilakukan pemeriksaan EEG dan diklasifikasikan sebagai normal dan abnormal. Manifestasi klinis berupa kejang, penurunan kesadaran, nyeri kepala dan panas telah dikumpulkan. Adanya hasil kultur positif TB dalam cairan serebrospinal dipertimbangkan sebagai meningitis TB definitif. Deskripsi EEG yang tidak normal diklasifikasikan sebagai abnormal I, II, dan III. Hubungan antara pola EEG dan manifestasi klinis dianalisis dengan uji eksak Fisher.

\section{HASIL}

Penelitian ini mendapatkan 12 kasus MT pada anak. Kebanyakan kasus bermanifestasi kejang, penurunan kesadaran dan panas. EEG abnormal didapatkan pada $75 \%$ anak dimana $77 \%$ diantaranya menunjukkan aktifitas epileptik. Hasil EEG banyak mendiskripsikan potensial epileptik di daerah frontotemporal. Didapatkan hubungan antara EEG yang tidak normal dengan manifestasi kejang pada anak dengan meningitis $T B(p<0.05)$.

\section{KESIMPULAN}

Pola EEG pada anak dengan MT bervariasi. Abnormalitas EEG lebih banyak didapatkan pada daerah frontotemporal. Kejang berhubungan dengan abnormalitas EEG pada anak dengan MT. Abnormalitas EEG yang terjadi bersamaan dengan kejang dapat memprediksi terjadinya kejang.

Kata kunci: Meningitis TB, elektro ensefalogram, anak

\section{INTRODUCTION}

Tuberculous meningitis (TBM) is one of the common infections of the central nervous system (CNS) representing a serious problem, not only in developing countries endemic to tuberculosis, but also worldwide, due to increased immigration. It is characterized by fever, headache, alterations of consciousness, vomiting, focal neurological deficits, and seizures. ${ }^{(1-3)}$ In many areas of Africa and Asia, the annual incidence of tuberculosis (TB) infection for all ages is approximately $2 \%$ and about $15 \%$ to $20 \%$ of these cases occur in children. TBM complicates about 1 in 300 of untreated cases of TB globally. ${ }^{(1,2)}$ In China, fiftyfour percent of patients aged 0 to 18 years had extrapulmonary tuberculosis (EPTB), and $38.8 \%$ suffered from TBM. ${ }^{(4)}$ TBM is still one of the common infections of the central nervous system and poses significant diagnostic and management challenges. ${ }^{(1)}$ The most common complications of TBM observed in 81 long-term survivors were epilepsy (11\%) and cognitive impairment (12\%). ${ }^{(5)}$ Seizures are a common clinical feature of TBM, 
occurring at any stage of the infection. They cause an additional burden of disability, producing neurological deficits which are a significant predictor of mortality, often requiring long-term antiepileptic therapy. ${ }^{(6)}$ Seizures can be the presenting feature of TBM, especially in children. ${ }^{(7)}$ Electroencephalography (EEG) has been reported to be better in assessing the gravity of lesions and was recently reported to help in prediction of outcomes. ${ }^{(8)}$ The EEG recordings in TBM depend on the site of the inflammatory process. Not much research has been reported on EEG abnormalities in TBM. Advanced neuroimaging has yielded valuable data about TBM pathological changes. The relation of clinical findings and EEG pattern may produce better understanding of TBM management and valuable prognostic clues. The objective of this study was to determine the correlation between EEG patterns and clinical manifestations in children with TBM.

\section{METHODS}

\section{Research design}

A cross-sectional design using medical records was conducted at Soetomo Hospital, Surabaya, Indonesia, from January 2012 to June 2013.

\section{Research subjects}

A total of 12 children with TBM were investigated. The age of the subjects ranged between 5 to 108 months and eight of them were males and four females.

\section{Measurements}

Clinical manifestations such as seizures, altered consciousness, headache or fever were recorded. The Glasgow coma scale (GCS) was applied to classify consciousness. The TBM diagnosis was based on history, clinical symptoms, and cerebrospinal fluid analysis. The evidence of tuberculosis outside the CNS and response to anti tubercular medication were also observed. The presence of a positive CSF Mycobacterium tuberculosis culture was considered to indicate a case of definite TBM. ${ }^{(8)}$ EEG recordings had been made on hospitalized children with TBM. The EEG descriptions were classified as abnormal EEG I, II or III. The level of EEG abnormalities depends on the clinical manifestations and correlates with the severity and specificity of cortical dysfunction of the EEG abnormality. A patient with mild slowing of the background activity associated with a mild diffuse functional cerebral disturbance is classified as abnormal I. If there is intermittent slow activity that is obviously localized or lateralized, then it should be classified as abnormal II. An EEG that shows spikes but is otherwise unremarkable is classified as abnormal III. ${ }^{(9)}$

\section{Statistical analysis}

The clinical manifestations and EEG patterns were analyzed by Fisher's exact test. Ap value of $<0.05$ was categorized as statistically significant.

\section{Ethical clearance}

The ethical clearance certificate had been issued by the Ethics Committee of Health and Research Dr. Soetomo Hospital.

\section{RESULTS}

Tuberculous meningitis cases were found in 12 children; the median age was 42 (range 5-108) months, eight (66.7\%) of them were males and four $(33.3 \%)$ females. The cases presented with seizures in $10(83.3 \%)$ children, decreased consciousness in 7 (58.3\%) children, fever in 9 (75.0) children, spasticity in $2(16.7 \%)$ children, headache in $2(16.7 \%)$ children, and hemiparesis in one child $(8.3 \%)$ (Table 1). Approximately two (16.7\%) children suffered from hydrocephalus.

The EEGs were abnormal in 8 (66.7\%) children, and $77 \%$ was categorized as abnormal III, $11.5 \%$ as abnormal II and $11.5 \%$ as abnormal I while $25 \%$ children had normal EEGs. The abnormal III EEG described epileptogenic activity mostly in the frontal (Figure 1) and temporal regions as follows: at the left frontal region in 2 children, left and right frontal regions in 1 , right frontotemporal region in 1 , left frontotemporal 
Table 1. Characteristics of the subjects

\begin{tabular}{lc}
\hline \multicolumn{1}{c}{ Clinic al Man ifestation } & n (\%) \\
\hline Characteri stics & \\
Sex & $8(66.7)$ \\
Boys & $4(33.3)$ \\
Girls & 42 months \\
A ge (Med an) & $5-108$ months \\
R ange & \\
N utritional status & $5(41.7)$ \\
Moder ately m alnourished & $7(58.3)$ \\
Severely m alnourished & \\
C linical m anifestations & $10(83.3)$ \\
Seizures & $7(58.3)$ \\
Decreased conciousnes & $9(75.0)$ \\
F ever & $2(16.7)$ \\
Headache & $2(16.7)$ \\
Spasticity & $1(8.3)$ \\
Hemiparesi s & \\
C T scan findings & $2(16.7)$ \\
Hydrocephalus & $1(8.3)$ \\
Infarction &
\end{tabular}

region in 1 , right and left temporal regions in 1 and in both hemispheres in the 6 remaining children. There was a significant relationship between seizures and EEG abnormalities $(\mathrm{p}<0.05)$ (Table 2).

\section{DISCUSSION}

In our research, the EEG recordings were found to be abnormal in $75 \%$ patients. The most common abnormalities were abnormal III in about $77 \%$. The epileptiform activity potentials were mostly in the frontal and temporal regions, at left frontal region in 2 children, left and right frontal region in 1 , right frontotemporal region in 1 , left frontotemporal region in 1, right and left temporal region in 1 and bilateral cerebral hemisphere region in 1 child.

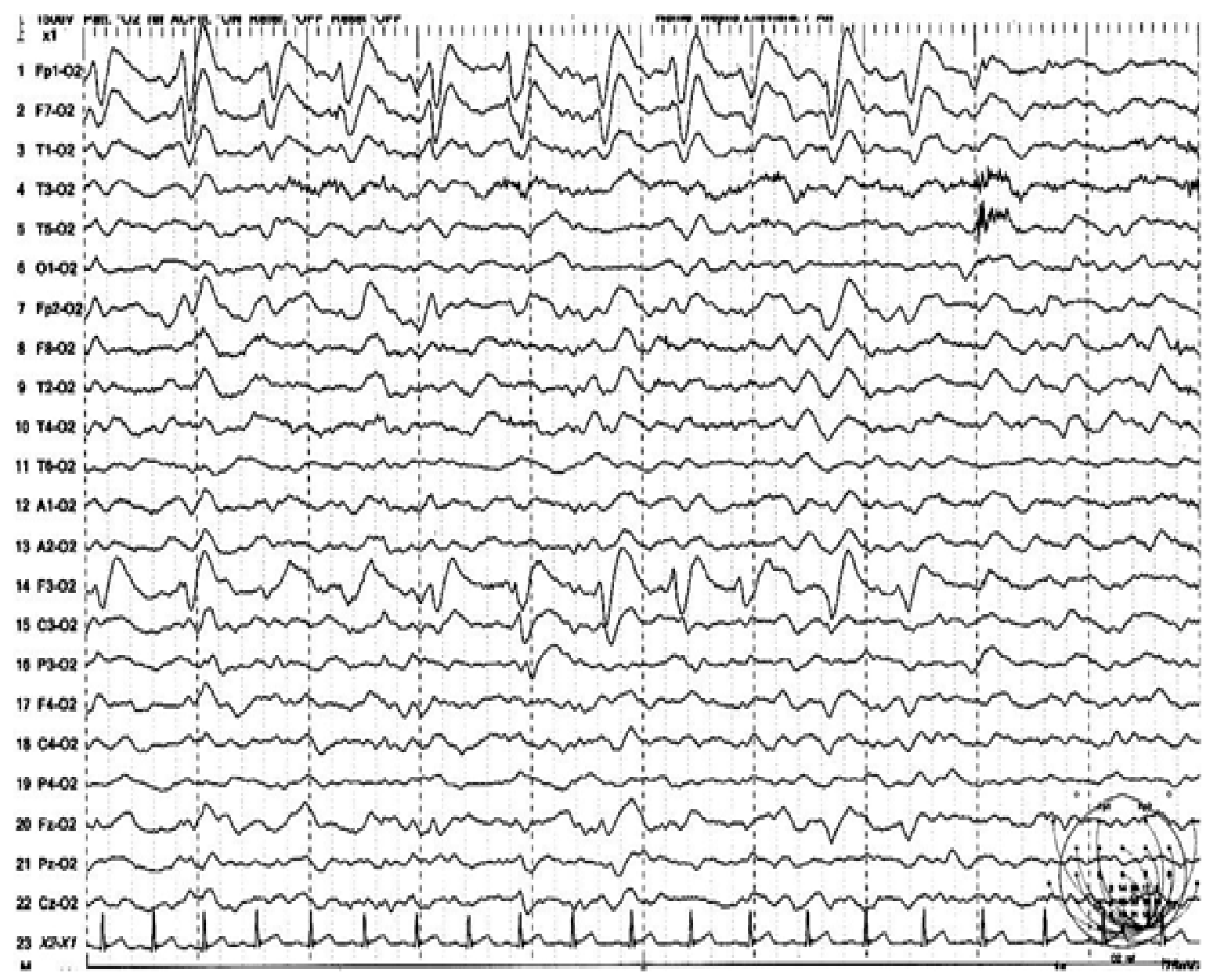

Figure 1. EEG pattern in one TBM patient showing epileptiform waves in left frontal region 
Table 2. Clinical manifestations and EEG patterns in TBM patients

\begin{tabular}{|c|c|c|c|}
\hline \multirow{2}{*}{ Clinical Manifestation } & \multicolumn{3}{|c|}{ EEG } \\
\hline & $\begin{array}{c}\text { Ab no rmal } \\
\text { n }(\%)\end{array}$ & $\begin{array}{l}\text { Normal } \\
n(\%)\end{array}$ & $\mathbf{p}$ \\
\hline \multicolumn{4}{|l|}{ Seizures } \\
\hline+ & $8(80.0)$ & $2(20.0)$ & $0.028 *$ \\
\hline- & $0(0.0)$ & $2(100.0)$ & \\
\hline \multicolumn{4}{|l|}{ Decrease of consciousness } \\
\hline+ & $5(71.4)$ & $2(28.6)$ & 1.001 \\
\hline- & $3(60.0)$ & $2(40.0)$ & \\
\hline \multicolumn{4}{|l|}{ Fever } \\
\hline+ & $7(68.8)$ & $2(22.2)$ & 0.241 \\
\hline- & $2(66.7)$ & $1(33.3)$ & \\
\hline \multicolumn{4}{|l|}{ Headache } \\
\hline+ & $1(50.0)$ & $1(50.0)$ & \\
\hline- & $3(30.0)$ & $7(70.0)$ & 1.000 \\
\hline \multicolumn{4}{|l|}{ Spasti dity } \\
\hline+ & $2(100.0)$ & $4(40.0)$ & 0.524 \\
\hline- & $6(60.0)$ & $0(0.0)$ & \\
\hline \multicolumn{4}{|l|}{ H emiparesis } \\
\hline+ & $1(100.0)$ & $0(0.0)$ & 1.000 \\
\hline- & $7(63.6)$ & $4(36.4)$ & \\
\hline
\end{tabular}

Tuberculosis of the central nervous system is the most serious complication of tuberculosis in children. Many kinds of pathologies may appear simultaneously in TBM, for instance, hydrocephalus, vasculitis, and edema, that result in ischemia, infarction or tuberculoma. The pathological changes in various or isolated combinations may determine EEG abnormality in TBM. EEG descriptions in TBM depend on the site of the inflammatory process. In case of basal meningitis, EEGs may be normal and may show mild unspecific changes. Mild to severe slowing of EEG background might be caused by the involvement of the cerebral cortex and meninges. The degree of slowing depends on the rate of progression of the disease process, the extent of cortical involvement, associated metabolic factors, medication and level of consciousness. In TBM, severe inflammation with proliferative changes and vasculitis may lead to changes in clinical symptoms such as level of consciousness disturbance ranging from delirium to coma, cranial nerve involvement, hemiplegia, hydrocephalus, and epileptic seizures. ${ }^{(10-12)}$

Our study showed that seizures observed clinically were present in 10 patients but epileptogenic activity were present in 8 patients, and the other patients had normal EEGs. There were two patients without seizures, one of whom had epileptogenic activity while the other had a normal EEG. This resulted in significant correlation between seizures and EEG abnormalities. The etiology of seizures in TBM is multifactorial and is related to pathophysiological changes occurring during the disease process. Cerebral edema, meningeal irritation, and raised intracerebral pressure are thought to represent the most probable causes of seizures in the early phase of TBM. Arman et al. ${ }^{(13)}$ reported a case with altered mental status who was diagnosed with non convulsive status epilepticus (NCSE). A workup to explain the etiology revealed TBM with increased cerebrospinal fluid protein and positive 
tuberculous DNA polymerase chain reaction and interferon- $\gamma$ assay tests.

In a study by Kalita el al., ${ }^{(14)}$ EEG descriptions were reported to be commonly abnormal in stage III TBM patients. Out of 21 patients in stage III, 19 had EEG abnormality whereas 2 out of 6 patients in stage II and 1 out of 5 in stage I patients had EEG abnormality. Epileptiform discharges were also present in stage III. Out of 4 patients with epileptiform discharges, clinical seizures were observed in 3. ${ }^{(14)}$ In TBM, EEGs may show at least moderate diffuse slowing with or without focal findings and epileptiform activity, depending on the severity of the clinical symptoms. ${ }^{(6,9)}$ Study by Kalita et al. ${ }^{(14)}$ showed that the EEG was abnormal in 11 patients which included delta slowing in 5, theta slowing in 6 , frontal intermittent rhythmic delta activity (FIRDA) in 3 and epileptiform discharges in 2 patients. ${ }^{(14)}$ Any CNS infection that affects the brain parenchyma may result in epileptic syndrome as a chronic sequel as well as acute seizures at the time of infection. Chronic phase epilepsy as a complication of CNS infection in TBM occurs in more than $20 \%$ of cases. ${ }^{(1)}$ A novel study focusing on advanced neuroinflammation and cellular injury in the field of pediatric epilepsy surgery has suggested a common pathogenic consequence in childhood epilepsy with different etiologies. The pathophysiologic basis of chronic epilepsy following CNS infection is not wellknown. Reactive gliosis following severe neuronal injury from changes in the local cellular and physiochemical environments have supported the likelihood of a common final pathway for seizure multiplication in various situations with many causes. ${ }^{(14,15)}$ Another study in African children showed that headache, convulsion, motor function, brainstem dysfunction, and cerebral infarction were independently associated with poor outcomes of TBM. ${ }^{(16)}$ A recent study has demonstrated that seizures associated with tuberculomas most often resolve after successful treatment of the underlying CNS tuberculosis. ${ }^{(17)}$ In this study, several clinical manifestations such as decreased consciousness, fever, headache, spasticity and hemiparesis had no signification correlation with EEG pattern. Head neuroimaging in childhood TBM with epileptiform discharges were abnormal in two and showed hydrocephalus and infarction in both. In the last remaining patients, head CT scans were obviously normal. ${ }^{(3)}$ In the study of Kalita et al., ${ }^{(14)}$ EEG results were associated with three months outcome. The abnormality pattern shown in the EEG descriptions of TBM has been correlated with poor outcome. The relative significance of different types of EEG changes in the prognosis of TBM would need a further study with consecutive long term follow-up. The EEG can often be a reliable predictor of outcome., and is most useful in differentiating organic from psychiatric conditions, in excluding nonconvulsive status epilepticus (NCSE), and in providing a rough guide as to the degree of cortical and subcortical dysfunction. ${ }^{(8,11)}$ Tuberculous meningitis starts with nonspecific symptoms and is often only diagnosed when brain damage has already occurred. The EEG continues to play a central role in diagnosis and management of patients with seizure disorders, because it is a convenient and relatively inexpensive way to demonstrate the physiological manifestations of abnormal cortical excitability that underlie epilepsy. ${ }^{(8)}$ Tuberculous meningitis is associated with a variable degree of encephalitis, which is primarily responsible for the altered sensorium. The other factors contributing to altered sensorium in TBM may include hydrocephalus, infarction, or tuberculoma in a strategic location. ${ }^{(18)}$ The overall prognosis of TBM remains poor, with $10-20 \%$ case fatality (worse if treatment is delayed and the patient is comatose) and 20-30\% long term morbidity (cognitive and behavioral impairment, epilepsy, cranial nerve palsies and paresis). ${ }^{(19)}$ Early diagnosis and treatment correlates with better outcomes. Given the difficulties in obtaining a rapid diagnosis, therapy must often be initiated empirically. ${ }^{(20)}$

In the present study, radiograph interpretation should have been performed, and EEG might be useful to monitor TBM patients, if interpreted by professionals in the field of clinicalradiological findings. This study shows the 
importance of EEGs to detect seizure activity and risk of epilepsy in children with TBM. For further research, it is necessary to conduct studies related to prognosis of children with TBM, especially those with abnormal EEGs, and to the quality of life of patients who survive the emergency.

\section{CONCLUSION}

The EEG pattern in children with TBM varies. Abnormal III in frontotemporal regions seems to be more common. Seizures were associated with EEG abnormalities in TBM. EEGs showing the presence of seizures may assist in localizing the site involved and predict seizure occurrence.

\section{CONFLICT OF INTEREST}

The authors declare no conflict of interest evidence related to this article.

\section{ACKNOWLEDGEMENT}

Our highest gratitude to Mangihut Rumiris for her contribution to data collection.

\section{REFERENCES}

1. Philip N, William T, Vanitha D. Diagnosis of tuberculous meningitis: challenges and promises. Malaysian J Pathol 2015;37:1-9.

2. Murthy JM. Management of intracranial pressure in tuberculous meningitis. Neurocrit Care 2005;2:306-12.

3. Paganini H, Gonzalez F, Santander C, et al. Tuberculous meningitis in children: clinical features and outcome in 40 cases. Scand J Infect Dis 2000;32:41-5.

4. Wu XR, Yin QQ, Jiao AX, et al. Pediatric tuberculosis at Beijing Children's Hospital: 2002-2010. Pediatr 2012;130:e1433-40.

5. Anderson NE, Somaratne J, Mason DF, et al. Neurological and systemic complications of tuberculous meningitis and its treatment at Auckland City Hospital, New Zealand. J Clin Neurosci 2010;17:1114-8.

6. Brigo F, Ausserer H, Zuccoli G, et al. Seizure heralding tuberculous meningitis. Epileptic Disord 2012;14:329-33.
7. Miftode EG, Dorneanu OS, Leca DA, et al. Tuberculous meningitis in children and adults: A 10-year retrospective comparative analysis. Plos One 2015;10:e0133477.

8. Smith SJM. EEG in the diagnosis, classification, and management of patient with epilepsy. J Neurol Neurosurg Psychiatry 2005;76 Suppl II:ii2-ii7.

9. Luders H, Noachtar S. Atlas and classification of electroencephalography. Philadelphia: Saunders;2006.

10. Park S, Hong YJ, Lee MK, et al. Hippocampal sclerosis and encephalomalacia as prognostic factors of tuberculous meningitis-related and herpes simplex encephalitis-related epilepsy. Seizure 2011;20:570-4.

11. Kaplan PW. The EEG in metabolic encephalopathy and coma. J Clin Neurophysiol 2004;21:307-18.

12. Ikeda A, Klem GH, Luders HO. Metabolic, infectious and hereditary encephalopathies. In: Ebersole JS, Pedley TA, editors. Current practice of clinical electroencephalography. $3^{\text {rd }} \mathrm{ed}$. Philadelphia: Lippincott Williams and Wilkins, 2003.p.348-77.

13. Arman F, Kaya D, Akgün Y, et al. Tuberculous meningitis presenting with nonconvulsive status epilepticus. Epilepsy Behav 2011;20:111-5.

14. Kalita J, Misra UK, Das BK. SPECT changes and their correlation with EEG changes in tuberculous meningitis. Electromyogr Clin Neurophysiol 2002;42:39-44.

15. Choi J, Nordli DR, Alden TD, et al. Cellular injury and neuroinflammation in children with chronic intractable epilepsy. J Neuroinflammation 2009;6: 38.

16. van Well GTJ, Paes BF, Terwee CB, et al. Twenty years of pediatric tuberculous meningitis: a retrospective cohort study in the Western Cape of South Africa. Pediatr 2009;123:e1-8.

17. Alsemari A, Baz S, Alrabiah F, et al. Natural course of epilepsy concomitant with CNS tuberculomas. Epilepsy Res 2012;99:107-11.

18. Misra UK, Kalita J, Roy AK, et al. Role of clinical, radiological, and neurophysiological changes in predicting the outcome of tuberculous meningitis: a multivariable analysis. J Neurol Neurosurg Psychiatry 2000;68:300-3.

19. Ginsberg L, Desmond K. Chronic and recurrent meningitis. Practical Neurol 2008; 8:348-61.

20. Christie L, Loeffler AM, Honarmand S, et al. Diagnostic challenges of central nervous system tuberculosis. Emerg Infect Dis 2008;14:1474-5. 